Ann. Biol. anim. Bioch. Biophys., I975, 15 (2), 317-327.

\title{
THE USE OF PROGESTAGEN SC 9880 AS AN AID FOR ARTIFICIAL INSEMINATION IN EWES
}

\author{
G. COLAS \\ with technical assistance of Y. Guerin \\ Station de Physiologie de la Reproduction, \\ Centre de Recherches de Tours, I. N. R. A., \\ 37380 Nouzilly (France)
}

\section{SUMMARY}

We have analysed the most favorable conditions for obtaining good fertility, prolificity and fecundity in non-lactating ewes treated with hormones (vaginally administered fluorogestone acetate and PMSG) and inseminated with either fresh (1 $\left.5^{\circ} \mathrm{C}\right)$ or frozen $\left(-196^{\circ} \mathrm{C}\right)$ semen, without prior detection of oestrus.

This study has shown that even during the breeding season, PMSG should be associated with progestagen, and that the results also depend on the quantity of hormone contained in the vaginal sponge. The technique of semen preparation and administration (quality of diluent, timing and number of inseminations, final semen concentration) is an equally important source of variation. The results presented indicate that the technique of synchronisation of oestrus with hormones associated with artificial insemination (fresh semen : I AI/female; frozen semen : 2 AI/female) can be used throughout the year, but we find slightly better results with fresh semen than with frozen semen.

It is now well-known that the use of progestagens to control estrus and ovulation in sheep cannot be dissociated from artificial insemination. More advantages may be obtained from estrus synchronization with AI than with natural service. Unfortunately, the decline in fertility which appears following the application of a progestagen treatment is more marked with artificial insemination than with mating (Lindsay et al., I967; Willemse, Brand and MURLing, Ig68), and the reasons for this phenomenon are not clearly elucidated.

The purpose of this paper is to review the three most important factors involved in the success of both oestrus synchronization and AI. Their effects have been studied on reproductive performances (fertility, prolificacy, fecundity) of nonsuckling ewes, artificially inseminated with liquid and deep-frozen semen. 


\section{MATERIAL AND METHODS}

\section{I. - Hormonal treatment}

Animals were treated with fluorogestone acetate (1) administered intravaginally (RoBINson, 1965) over a period of twelve days (anestrous period) or fourteen days (sexual season). Sponges were impregnated with $30 \mathrm{mg}$ in the non-breeding season (THIMONIER and CoGNIE, I97I), and with $40 \mathrm{mg}$ in the sexual season (Colas et al., 1973). In some cases, pessary withdrawal was followed by PMSG treatment (400-450 IU in the breeding season, 600-650 IU in the non-breeding season). PMSG injection always took place in the morning between 7.30 hours and 9.30 hours.

\section{2. - Management}

The majority of the sheep (dairy and meat animals) belonged to private flocks. Using aproned rams, oestrus was detected by the shepherd twice daily between 7-9 a.m. and 5-6 p.m. during the first and the second oestrus periods after progestagen treatment.

\section{3. - Avtificial insemination}

AI was always performed at a predetermined time during the first induced oestrus. The number of spermatozoa inseminated per cwe was :

- $500 \times 10^{6}$ total spermatozoa for fresh semen,

- 360-400 $\times 10^{6}$ motile spermatozoa for frozen semen.

During the second oestrus, ewes were inseminated :

- either once daily for 2 days ( $500 \times 10^{6}$ spermatozoa/female) (table 1 ), when detected in oestrus,

- or, once daily for five days from day 18 to day $22\left(250 \times 10^{6} \mathrm{spermatozoa/day/female}\right)$, on a time basis. These ewes werc inseminated only at the second estrus and were used to compare the fertilization rates of both first and second estruses after hormonal treatment (table 4).

Semen was collected by artificial vagina. It was diluted and frozen as previously described (Colas et al., I973; Colas, I975). When first and second estruses were compared, ewes were inseminated in both cases with the semen of the same rams. Time elapsed between previous parturition and AI was never less than go days.

\section{RESUITS}

$$
\text { I. - Effect of } P M S G
$$

It was demonstrated by QUINLIVAN and RoBINSON (1967, I969) that progestagens disturb transport and survival of spermatozoa in the female genital tract; this usually leads to lower fertility during the first estrus induced by hormonal treatment. Table I confirms this observation, which has been often reported in the literature. The fertility and fecundity $\left({ }^{2}\right)$ of treated animals are strongly reduced, while prolificacy remains unchanged.

However, this subfertility does not appear with the same intensity in all the animals. Table 2 shows that when progestagen only is given, fertility, prolificacy and fecundity are closely related to the time elapsed between the end of treatment and the onset

(1) Fluorogestone acetate = FGA (r 7 -acetoxy-9 fluoro-II hydroxy-pregn-4-ene 3.20 dione) $=\mathrm{SC} 9880$.

(2) Fertility, prolificacy and fecundity are expressed as indicated by Desvignes and Darpoux (I964). 
of estrus. When this time interval is 36 hours, fertility with fresh semen is similar in animals inseminated during the first or second estrus after treatment : $72.8 \mathrm{p}$. Ioo vs 72.0 p. IOO in table I. When this time interval is 48 hours, the values of the three criteria decrease, the animals, in both cases, being inseminated at the same time after sponge removal (50 and 60 hours). This phenomenon appears still more clearly in animals inseminated with frozen semen. For example, fecundity is sharply reduced when ewe comes in estrus only $4^{8}$ hours after withdrawal of the sponge.

TABLE， I

Effect of the sole progestagen treatment (40 mg FGA)

on the reproductive performances

of non suckling ewes artificially inseminated with fresh semen

\begin{tabular}{c|c|c|r}
\hline $\begin{array}{c}\text { Oestrus after } \\
\text { sponge removal }\end{array}$ & Fertility (\%) & Prolificacy (\%) & Fecondity (\%) \\
\hline & & & \\
\hline & & & \\
\hline First & $54.5(311)$ & $147.0(177)$ & $83.5(311)$ \\
& $72.0^{*}(111)$ & $150.5(91)$ & $123.5(111)$ \\
\hline
\end{tabular}

( ) : Inseminated or lambing ewes.

$*: \mathrm{P}<0.01$.

TABLE, 2

Relationship between termination of progestagen treatment (hours) and onset of oestrus and the reproductive performances of non suckling ewes

(ewes are given no PMSG they are inseminated

$5^{\circ}$ and 60 hours after sponge removal)

\begin{tabular}{|c|c|c|c|c|c|c|}
\hline \multirow{2}{*}{ Sperm } & \multicolumn{2}{|c|}{ Fertility $(\%)$} & \multicolumn{2}{|c|}{ Prolificacy $(\%)$} & \multicolumn{2}{|c|}{ Fecondity $(\%)$} \\
\hline & $36 \mathrm{hrs}$ & $48 \mathrm{hrs}$ & $36 \mathrm{hrs}$ & $48 \mathrm{hrs}$ & $36 \mathrm{hrs}$ & $48 \mathrm{hrs}$ \\
\hline Fresh $\left(+15^{\circ} \mathrm{C}\right)$ & $72.8 \quad(22)$ & $60.0 \quad(55)$ & $168.0(16)$ & $163 \quad(33)$ & $123.5(22)$ & $98.5 \quad(55)$ \\
\hline Frozen $\left(-196^{\circ} \mathrm{C}\right)$ & $55.0 \quad(20)$ & $21.8(101)$ & $181.5(11)$ & $122.8(22)$ & $100.0(20)$ & $26.7(101)$ \\
\hline Total & $64.3^{*}(42)$ & $35.3(156)$ & $174.0(97)$ & $147.2(55)$ & $112.0(42)$ & $51.9(156)$ \\
\hline
\end{tabular}

( ) : Inseminated or lambing ewes.

* : 36 vs. $48 \mathrm{~h}: \mathrm{P}<0.05$.

A possible explanation of these results is given by the relationship which exists between the occurrence of oestrus and its duration. The later the onset, the smaller the duration of oestrus, and it has been demonstrated that a short oestrus is always associated with lower fertility rate (LOPYRIN and Loginova, I960 ; ColaAs, I968). 
It has been well established by GoRdon (I967), CoGNre et al. (I968, I970) and others that, apart from its effect on ovulation rate and synchronization of ovulation, PMSG may advance onset of oestrus. Thus, a hormone injection must increase the proportion of ewes coming in oestrus 36 hours after sponge withdrawal and, consequently, their fertility. This appears in table 3 , where the proportion of animals detected in oestrus during the breeding season 36 hours after sponge withdrawal increases from 5.3 to 53.2 , while the total onset of estrus remains unchanged (I00.0 p. Ioo vs 99.2 p. IOO).

TABLE 3

Effect of PMSG on the onset of oestrus after treatment with FGA (40 $\mathrm{mg})$ during the breeding season

\begin{tabular}{|c|c|c|c|c|c|}
\hline \multirow{2}{*}{$\begin{array}{l}\text { PMSG } \\
(\mathrm{IU})\end{array}$} & \multirow{2}{*}{$\begin{array}{l}\text { Ewes }\left({ }^{1}\right) \\
\text { treated }\end{array}$} & \multicolumn{4}{|c|}{$\begin{array}{l}\text { Ewes in oestrus (\%) } \\
\text { after sponge removal (hrs) }\end{array}$} \\
\hline & & 36 & 48 & $>48$ & Total \\
\hline 0 & 112 & $5.3(6)$ & $81.2(91)$ & $14.5(15)$ & 100.0 \\
\hline 400 & 111 & $53.2(59)$ & $46.0(51)$ & $\ldots$ & 99.2 \\
\hline
\end{tabular}

(1) Ile-de-France ewes.

( ) : Inseminated or lambing ewes.

The lambing results following a predetermined insemination time at first or second oestrus after sponge withdrawal are equivalent to when ewes are given PMSG (table 4: respectively 69.0 p. IOO vs 7 I. 8 p. I00). PMSG has still more marked effect on sheep reproduction when sperm is frozen. Fecundity is then three times higher in ewes injected with PMSG.

\section{TABLE 4}

Effect of PMSG on reproductive performances of non suckling ewes treated by $F G A$ and inseminated artificially during the breeding season

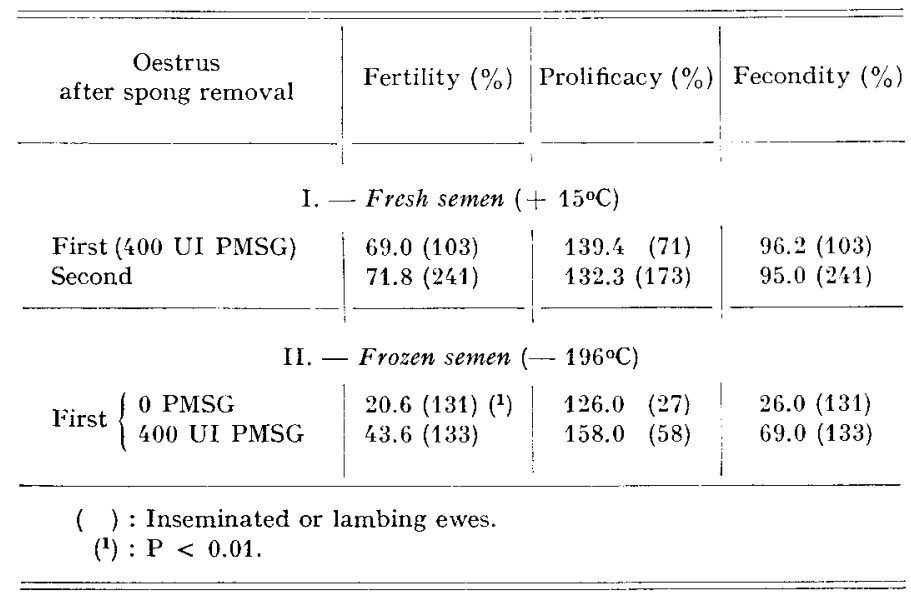




\section{2. - Effect of methods on sperm preparation and insemination}

a) Diluent and sperm treatment.

The conditions adverse to progression and survival of spermatozoa in the female in which estrus has been induced by FGA, suggest that semen quality is of great importance to the success of fertilization. When AI is used, it is essential to choose an extender able to protect the fertilizing power of the sperm cells. Table 5 indicates clearly that, in both fresh and frozen semen, diluents containing egg yolk reduce fertility in ewe. In frozen semen, the results are closely dependent upon the handling method of the semen (table $6:$ for example 52.0 p. Ioo vs 75.0 p. Ioo conception rate with freezing methods I and 2).

\section{TABIE 5}

Effect of diluent on the fertility of the ewes treated with FGA + PMSG (Within each comparison, the same number of spermatozoa have been used for both diluents)

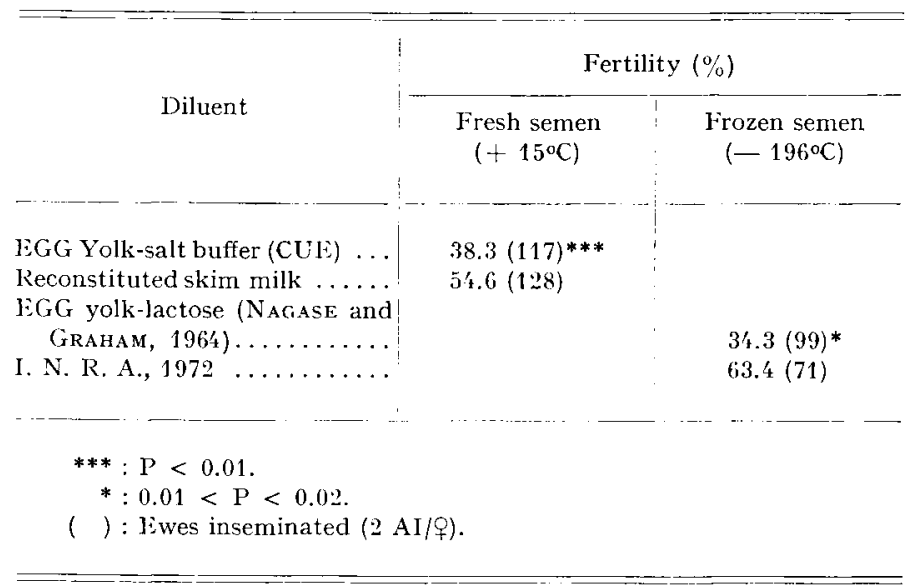

TABLE 6

Effect of the freezing method on the reproduction of FGA + PMSG treated ewes

\begin{tabular}{l|c|r|r}
\hline Freezing method & Fertility (\%) & Prolificacy (\%) & Fecundity (\%) \\
\hline 1 (CoLAS, 1975) & $75.0(94)$ & $200.0(71)$ & $150.0(9 \%)$ \\
2 (unpublished) & $52.0 *(96)$ & $180.0(50)$ & $94.0(96)$ \\
\hline
\end{tabular}

( ) : Inseminated or lambing ewes.

$*: \mathrm{P}<0.01$. 
b) Insemination of ewes.

Since the onset of oestrus following use of FGA and PMSG occurs over a very short period (about I2 hours), it is necessary to determine exactly the optimum period at which sperm should be deposited in order to have the best chance of fertilization. This is especially important because the survival capacity of spermatozoa in the uterus is reduced when the female is synchronized (QuinLIVAN and RoBINSon, I967, HAWK and CONLEY, I97I). If AI is carried out without detection of oestrus, an error in the time of insemination will result in lower fertility.

We have studied this problem in cyclic and anestrous ewes. Results presented in table 7 show that the optimum period for insemination ranges between 48 and 60 hours after sponge withdrawal.

TABLE 7

Effect of $A I$ timing (hours) on the reproductive performances of non suckling ewes (breeding season) (1)

I. $-2 \mathrm{AI} /$ ㅇ $\left(500 \times 10^{6} \mathrm{spz} /\right.$ \% . Fresh semen $)$

\begin{tabular}{|c|c|c|c|}
\hline $\begin{array}{c}\text { AI schedule } \\
\text { from end of } \\
\text { treatment (hours) }\end{array}$ & Fertility $(\%)$ & Prolificacy $\left({ }^{2}\right)(\%)$ & Fecundity $(\%)$ \\
\hline 36 and 48 & $48.8(133)$ & $149.0(65)$ & $73.0(133)$ \\
\hline 36 and 60 & $50.4(131)$ & $144.0(66)$ & $72.5(133)$ \\
\hline 48 and 60 & 60.5 (139) & $164.2(84)$ & $99.4(139)$ \\
\hline
\end{tabular}

(1) From Colas, Thimonier, Courot, Ortavant (1973).

(2) $0.01<\mathrm{P}<0.05$.

( ) : Inseminated or Lambing ewes.

In reality, a more detailed analysis shows that in spring as in autumn, this optimum period is situated between 55 and 60 -hours after PMSG injection, which is therefore very short (about 5 hours). We have also observed that the proportion of twins is highest when spermatozoa are introduced 55 hours after PMSG injection, but this needs to be checked on a much larger number of ewes.

\section{3. - Efficiency of FGA + PMSG treatment and $A I$ all year long}

The last two tables 8 and 9 show results obtained all year long with hormonal treatment and AI. When ewes (Ile-de-France) are inseminated with fresh semen, the lambing performances appear constant in all months of the year.

When animals receive frozen semen, the tendency is similar but the results are lower. 
TABLE 8

Effect of AI timing (hours) on the fertility of non suckling ewes (1) II. - I AI/ \% $\left(500 \times \mathrm{ro}^{6} \mathrm{spz} . /\right.$. . Fresh semen $)$

\begin{tabular}{|c|c|c|c|}
\hline & \multicolumn{3}{|c|}{ AI } \\
\hline & 50) hrs & 55 hrs & $60 \mathrm{hrs}$ \\
\hline Sexual (summer) & $57.2(117)$ & $61.3(119)$ & $62.6(115)$ \\
\hline Anoestrus (spring) & $62.2(127)$ & $70.5(132)$ & $6.5(131)$ \\
\hline
\end{tabular}

( ) : Inseminated or lambing ewes.

(1) From Colas, Brice, Guerin (1974).

TABLE 9

Efficiency of the FGA + PMSG treatment and of $A I$ during the year

\begin{tabular}{|c|c|c|c|c|c|c|c|}
\hline \multicolumn{8}{|c|}{ I. - Fresh semen } \\
\hline \multirow[b]{2}{*}{$\begin{array}{l}\text { Fertility } \\
(\% \text { CR })\end{array}$} & \multicolumn{2}{|c|}{ lebruary } & April & May & \multicolumn{2}{|c|}{ July } & November \\
\hline & \multicolumn{2}{|c|}{$72.0(50)$} & $73.0(48)$ & $65.0(46)$ & \multicolumn{2}{|c|}{$76.0(60)$} & $76.0(48)$ \\
\hline \multicolumn{8}{|c|}{ II. - Frozen semen } \\
\hline & \multicolumn{3}{|c|}{ Fertility (\%) } & \multicolumn{2}{|c|}{ Prolificacy $(\%)$} & \multicolumn{2}{|c|}{ Fecondity $(\%)$} \\
\hline \multicolumn{2}{|c|}{$\begin{array}{l}\text { Breeding season } \\
\text { Anoestrus period }\end{array}$} & & $\begin{array}{l}59.2(145) \\
53.7(108)\end{array}$ & \multicolumn{2}{|c|}{$\begin{array}{l}156.0(134) \\
158.5(58)\end{array}$} & \multicolumn{2}{|c|}{$\begin{array}{l}92.5(145) \\
85.0(108)\end{array}$} \\
\hline \multicolumn{8}{|c|}{ ( ) : Inseminated or lambing ewes. } \\
\hline
\end{tabular}




\section{DISCUSSION}

The results reported in the present study show that it is possible to obtain normal fertility in the non-suckling ewe following use of SC 9880 , if certain conditions are satisfied.

We have emphasized the importance of PMSG, for it seems to us to be one of the most favorable factors in the success of the progestagen treatment in conjunction with set-time AI. Many authors previously studied its effect in the anestrous ewe, and concluded PMSG necessary to improve fertility. At that period of the year, progestagen only is not sufficient in inducing oestrus in all the treated animals (RoBInson, I970; Gordon, I972; Pelietier and ThimonizR, I975). Therefore, the fecondation rate at the oestrus immediately after treatment, relative to the total number of animals, is generally low.

When the females are in complete sexual activity (breeding season), PMSG administration also raises fertility, but this is not due to better oestrus response since all ewes come in oestrus after end of treatment. The increase is particularly marked when spermatozoa have been frozen at a very low temperature and it is well known that the biological properties of these cells are always reduced. This means poor survival power in the female tract (LoGINOVA and ZHELTOBRUKH, I968), poor fertilizing capacity (SALAMON, I97I), and release of membrane-bound phospholipid (DARING-BENNETT et al., I973). Ovulations being more synchronized following use of PMSG, the meeting conditions of male and female gametes are improved, which leads to better fertility and prolificacy rates. Gonadotropin hormone properties differ according to season and storage temperature of sperm, and good results all year long may be obtained.

However, the question arises whether repeated use of PMSG in the same ewe causes antibody production and thus diminishes the activity of the injected hormone, as has been demonstrated for HCG in rabbit (ADAM, I972). Using usual techniques (Dubors and ColAs, I974, unpublished), preliminary results on Lacaune dairy ewes, treated each year over a five-year period, show that antibodies do not occur at a significant rate.

The elements which are involved in the protection of the quality of the semen, especially the diluent, must also be considered. This problem has been studied in detail for frozen semen by Salamon and LightFoot (i969), Salamon and Visser (r972), KARE'TA et al., (I972). On the other hand, less attention has been given to the composition of extenders for fresh sperm, which is often diluted in egg yolk solutions. These media being satisfactory when ewes are in natural estrus, it seems logical to also use them for inseminating progestagen + PMSG treated ewes. MAMPOUYA (I973) has shown that the activity of spermatozoa incubated at $+3^{\circ} \mathrm{C}$ declines more rapidly when they are diluted in an egg yolk solution than in a suspension of skim milk powder. Duration of spermatozoon migration through the female genital tract being lengthened by the hormonal treatment, it is not surprising to obtain a lower conception rate following use of egg yolk containing diluents.

The results presented in table 8 concerning the effect of AI timing on fertilization rate would tend to indicate that lambing performances are higher during the 
non-breeding season than during the sexual season. This is only due to the fact that in the second period (breeding season), we used milked females at the end of lactation (Lacaune ewes). In previous experiments, we have often observed that fertility results are poorer in these animals than in dry ewes. This lower fertility is probably caused by lactation, as the work of COGNrE (I975) indicates.

The period during which the chance of fertilization is the highest is very short after a progestagen + PMSG treatment, especially when ewes are in anoestrus. The drop in fertility is less important in summer than in spring, probably because the duration of oestrus is longer when animals are in sexual activity. This means that the time of insemination has to be more exact in the non-breeding season than in the breeding season. A high fertility level (72.0 p. Ioo conception for a single spring insemination - March to June - on 900 ewes) is attained with one insemination of a large number of spermatozoa at the most favorable moment.

\section{CONCLUSION}

Normal fertility after progestagen (FGA) treatment and artificial insemination depends upon three main factors :

- injection of PMSG even during the breeding season,

- use of a satisfactory diluent,

- insemination at an exact time after pessary withdrawal.

The number of spermatozoa per ewe, which has not been studied here, must also be important. In our experiments, the quantities of cells we have used for fresh semen and for frozen semen are high. Recent data have shown that it is not possible to reduce the number much without impairing fertility.

In these conditions, fertility level remains high all year long, especially with fresh semen. Both techniques should develop rapidly in the near future. For example, in France 80.000 ewes were inseminated after hormonal treatment and AI in I974.

\section{Colloque : Control of sexual cycles in domestic animals} October 27-30, 1974, Nouzilly.

\section{RÉSUMÉ}

SYNCHRONISATION DE L'CESTRUS PAR L'ACÉTATE DE FLUOROGESTONE ET INSÉMINATION ARTIFICIELLE CHEZ LA BREBIS

Nous avons étudié les conditions les plus favorables à l'obtention de bonnes performances (fertilité, prolificité et fécondité) chez la brebis sèche traitée avec des hormones (acétate de fluorogestone et PMSG) et inséminée avec du sperme frais $\left(+I 5^{\circ} \mathrm{C}\right)$ ou congelé $\left(-196^{\circ} \mathrm{C}\right)$ sans détection préalable d'ostrus.

Cette étude a montré que même pendant la saison sexuelle, la PMSG doit être associée au progestagène et que les résultats dépendent aussi de la quantité d'hormone contenue dans les éponges. La technique de préparation du sperme et de sa mise en place (qualité du dilueur, moment et nombre d'inséminations, concentration finale en spermatozoïdes) sont également d'importantes 
sources de variation des résultats. Ces derniers indiquent que la technique de synchronisation des oestrus par les hormones (FGA + PMSG) associée â l'IA (semence fraîche, I IA/오, semence congelée, $2 \mathrm{IA} /$ P) peut être utilisée tout au long de l'année. Les résultats obtenus sont légèrement meilleurs avec le sperme frais qu'avec le sperme congelé.

\section{REFERENCES}

Adams C. T., 1972. Induction of ovulation and AI. Techniques in the rabbit. Vet. Rec., 91, I94-I97.

Cognie Y., Thimonier J., Mauleon P., ig68. Etude du moment d'ovulation chez la Brebis après traitement progestatif, administré par voie vaginale et injection de PMSG, pendant la période d'anœstrus saisonnier. VIe Cong. Int. Reprod. anim. Insém. artif., Paris, vol. 2, 1403-1406.

Cognie Y., Mariana J. C., Thimonier J., ig7o. Étude du moment d'ovulation chez la Brebis normale et traitée par un progestagène associé ou non à une injectin de PMSG. Ann. Biol. anim. Bioch. Biophys., 10, $\mathrm{x}_{5}-24$.

Cognie Y., Hernandez-Barreto M., Saumande J., I975. Low fertility in nursing ewes during the non-breeding season. Ann. Biol. anim. Bioch. Biophys., 15, 329-343.

Colas G., I968. Durée de l'œstrus et fertilité après insémination artificielle chez la Brebis. VI Cong. intern. Reprod. anim. Insem. artif., Paris, vol. 2, Ior7-IoI9.

Colas G., Dauzier L., Courot M., Ortavant R., Signoret J. P., ig68. Résultats obtenus au cours de l'étude de quelques facteurs importants de l'insémination artificielle ovine. Ann. Zootech., $17,47-57$.

Colas G., Thimonier J., Courot M., Ortavant R., I973. Fertilité, prolificité et fécondité pendant la saison sexuelle des brebis inséminées artificiellement après traitement à l'acétate de fluorogestone. Ann. Zootech., 22, 44I-45I.

Colas G., Brice G., Guerin Y., 1974. Acquisitions récentes en matière d'insémination artificielle ovine. Bull. Tech. Inform. Minist. Agric, 294, 795-80o.

ColAs G., 1975. Effect of freezing temperature, addition of glycerol and dilution on the survival and fertilizing ability of deep-frozen ram semen. J. Reprod. Fert., 42, 277-285.

Darin-Bennett A., Poulos A., White I. G., i973. The effect of cold shock and freeze-thawing on release of phospholipids by ram, bull and boar spermatozoa. Aust. J. Biol. Sci., 26, I409-2o.

Desvignes A., Darpoux R., I964. Valeurs d'élevages des brebis utilisées pour le traitement industriel avec différentes races de béliers. Bull. Techn. Inf., 195, 293-90I.

GORDON I., I967. Induction of early breeding in sheep by standard and modified progestagen PMSG treatments. J. A gric. Sci., Cam., 76, 337-341.

GoRdon I., 1972. Control of reproduction in sheep : towards programmed lamb production. Departement's $J ., 68$.

HAwK H. W., Conley H. H., r97r. Loss of spermatozoa from the reproduction tract fo the ewe and intensification of sperm "breakage" by progestagen. J. Reprod. Fert., 27, 337-347.

Kareta W., Pilch J., Wierzbowski S., 1972. Fertility of frozen ram semen diluted in citrate added bull seminal plasma or not. Proc. 7th. Int. Congr. Anim. Reprod. A. I., Munich, vol. 2, I479-1485.

Lindsay D. R., Moore N. W., Robinson T. J., Salamon S., Shelton J. N., ig6\%. The evaluation of an oral progestagen (Provera, MAP) for the synchronisation of oestrus in the entire cyclic Merino ewe. In : The control of the ovarian cycle in the sheep, Ed. T. J. Robinson, Sydney N. S. W., Sydney University Press, 3-I7.

Loginova N. V., Jeltobruch N. A., I 968 . Experimental test of different methods of ram sperm freezing. VI $T^{\mathrm{e}}$ Cong. intern. Reprod. anim. Insem. artif., Paris, vol. 2, 1077-1080.

Lopyrin A. I., Loginova N. V., rg6o. L'insémination artificielle des brebis, Sel' Khozgiz, Moscou.

Mampouya C., I973. Étude de la survie et de la fécondance du sperme de bélier après conservation à l'état liquide et congelé. Thèse Dr $3^{\mathrm{e}}$ cycle, Clermont-Ferrand.

Nagase H., Graham E. F., I964. Pelleted semen : comparison of different extenders and processes on fertility of bovine spermatozoa. Ve Cong. intern. Reprod. anim. Insem. artif., Trente, vol. 4, 387-391.

Pelletier J., Thimonier J., 1975. Interactions between ovarian steroids or progestagens and LH release. Ann. Biol. anim. Bioch. Biophys., 15, r31-146.

Quinlivan T. D., Robinson T. J., I967. The number of spermatozoa in the fallopian tubes of ewes at intervals after artificial insemination following withdrawal of SC 9880 impregnated intravaginal sponges. In : The control of the ovarian cycle in the sheep. Ed. T. J. Robinson, Sydney N. S. W., Sydney University Press, $177-194$.

Quinlivan T. D., Robinson T. J., 1969. Numbers of spermatozoa in the genital tract after artificial insemination of progestagen treated ewes. J. Reprod., Fert., 19, 73-86.

RoBinson T. J., 1965. Use of progestagen impregnated sponges inserted intravaginaly of subcutaneously for the control of the oestrus cycle in the sheep. Nature, 206, 39-4r. 
Robinson T. J., I97I. The seasonal nature of reproductive phenomena in the sheep. II. Variation in fertility following synchronisation of oestrus. J. Reprod. Fert., 24, 19-27.

Salamon S., I97I. Fertility of ram spermatozoa following pellet freezing on dry ice at -79 and $-\mathrm{I} 40^{\circ} \mathrm{C}$. Aust. J. Biol. Sci., 24, 183-185.

Salamon S., Lightfoot R. J., I969. Freezing ram spermatozoa by the pellet method. I. The effect of diluent composition on survival of spermatozoa. Aust. J. Biol. Sci., 22, 1527-46.

Salamon S., Visser I), x972. Effect of composition of tris-based diluent and of thawing solution on survival of ram spermatozoa frozen by the pellet method. A A st. J. Biol. Sci., 25, 605-618.

Thimonier J., Cognie Y., r97r. Accélération des mises bas et conduite d'élevage chez les ovins. Bull. Tech. Inform. Minist. A gric., 257, I87-196.

Willemse A. H., Brand A., Murling F., I968. Oestrus synchronisätion in texel sheep. Titjdschr. Diergeneesk., 93, 66-82. 